\title{
Sistem Inspeksi Kecacatan pada Kaleng Menggunakan Filter Warna HSL dan Template Matching
}

\author{
Budi Sugandi*, Sintya Dewi \\ Jurusan Teknik Elektro \\ Politeknik Negeri Batam \\ Batam \\ *budi_sugandi@polibatam.ac.id
}

\begin{abstract}
Abstrak-Dalam industri makanan dan minuman dengan kemasan kaleng, pengecekan atau inspeksi kecacatan kaleng merupakan bagian penting dalam menjaga kualitas sebuah produk. Inspeksi tersebut sebagian masih menggunakan operator manual yang bergantung pada penglihatan para pekerja dengan segala keterbatasannya. Untuk menanggulangi masalah tersebut, artikel ini mengusulkan proses inspeksi kecacatan menggunakan filter warna HSL dan template matching berbasis contour analysis yang dilakukan secara otomatis tanpa bantuan operator. Proses inspeksi diawali dengan pengambilan citra RGB oleh kamera. Citra RGB tersebut kemudian dikonversi ke citra aras keabuan (gray leve). Untuk dapat mendeteksi kecacatan, penulis memakai filter luminance dari ruang warna HSL. Proses template matching diterapkan pada masing-masing citra dengan cara membandingkan contour citra template sebagai contour citra referensi dengan contour citra uji. Kemasan kaleng yang digunakan sebagai template mempunyai diameter $4 \mathrm{~cm}$. Dengan menggunakan kriteria uji jarak masing-masing pixel pada tiap lingkaran kaleng dengan lingkaran pada kaleng template, kaleng diklasifikasikan menjadi dua kategori yaitu kaleng $O K$ (Good) atau reject. Hasil pengujian menunjukkan, dengan menerapkan nilai threshold sebesar $4 \mathrm{~cm}$, nilai RMS untuk objek kategori OK adalah 0,59. Sementara untuk objek kategori reject didapatkan nilai RMS sebesar 19,59; 5,05 dan 15, 05 berturut-turut untuk objek reject karena diameter tidak beraturan, objek reject dengan pembuka kaleng terbuka dan objek reject tanpa pembuka kaleng.
\end{abstract}

Kata kunci: inspeksi kecacatan; filter warna HSL; template matching, contour analysis

\section{Pendahuluan}

Dalam kehidupan sehari-hari, kita sering mengkonsumsi bermacam-macam makanan atau minuman dengan kemasan kaleng. Setiap kemasan kaleng dalam satu produk pasti memiliki bentuk yang sama. Pengecekan kecacatan pada kemasan kaleng sebagian besar dilakukan secara manual menggunakan operator manusia yang prosesnya bergantung pada penglihatan mata para pekerja. Penglihatan manusia tentu saja memiliki keterbatasan akibat kelelahan maupun kekurangtelitian dalam pengecekan, sehingga membutuhkan tenaga pekerja yang banyak untuk memastikan akurasinya.

Beberapa studi telah dilakukan untuk mengatasi permasalahan di atas. Salah satunya dengan menggunakan deteksi kelainan tekstur objek yang akan dibandingkan [1]. Dalam studinya, penelitian ini mengklasifikasi objek berdasarkan objek rusak atau tidak. Proses pengklasifikasian menggunakan metode Principal Component Analysis (PCA). Sementara itu untuk menjamin kualitas kaleng agar produk yang dikemas terstandardisasi dan untuk meminimisasi kerusakan kaleng, pengontrolan kualitas kaleng menjadi sangat penting. Klasifikasi kaleng jenis reject pada beberapa ukuran volume kaleng juga pernah dilakukan sebelumnya [2]. Metode yang digunakan adalah Statistical Process Control (SPC) dan Statistical Quality Control (SQC).

Pendeteksian objek berwarna sering kali menggunakan filter warna, baik itu filter warna RGB, HSL/HSV, maupun YCbCr [3]-[11]. Filter warna HSL/ HSV banyak digunakan oleh banyak peneliti khususnya di bidang object recognition [3], machine vision [11] maupun robot vision [8], [10]. Penggabungan pendeteksian filter warna HSL dengan partikel filter sebagai metode untuk pelacakan objeknya berhasil memisahkan citra wajah dari citra latar dengan mengatur nilai filter warna HSL[3]. Sementara penggabungan metode pendeteksian objek dengan filter warna HSV dengan metode klasifikasi KNN (K Nearest Neighbor) dilakukan untuk mengklasifikasi objek berdasarkan data latih yang dibandingkan dengan data uji yang ada[11]. Penelitian ini berhasil mendeteksi dan mengklasifikasikan objek dengan tingkat akurasi 88.75\% untuk objek tanpa citra latar dan 77,35\% untuk objek dengan citra latar. Dalam bidang robot vision, filter warna HSV digunakan untuk mendeteksi gawang [10]. Hasil dari pendeteksian gawang akan menjadi referensi bagi robot untuk menentukan lokasi dirinya terhadap gawang.

Metode template matching merupakan metode untuk membandingkan citra referensi (template) dengan citra uji. Template matching telah banyak digunakan dalam beberapa 
studi di bidang biometrik [12]-[14] maupun bidang pengenalan objek (object recognition) [15]-[17]. Metode template matching untuk biometrik dengan membandingkan ciri pada citra uji dan citra referensi telah dilakukan oleh [12]. Penelitian ini membandingkan beberapa ciri dalam satu citra wajah uji dengan ciri-ciri citra referensi. Ciri citra yang digunakan adalah nilai intensitas dari pixel tiap citra wajah. Metode ini banyak kelemahan karena citra wajah sangat sensitive terhadap cahaya. Perhitungan cross correlation antara citra uji dan citra referensi menunjukkan hasil yang menjanjikan [14]. Hanya saja dengan citra uji dan referensi yang banyak akan memerlukan waktu pemrosesan yang lama. Selain itu untuk beberapa kasus mempuyai akurasi yang rendah. Sementara itu untuk penggunaan template matching pada pengenalan objek telah dilakukan [17]. Penelitian ini menggabungkan template matching dengan algoritma Artificial Bee Coloni. Penelitian ini berhasil mendeteksi objek dengan akurasi 100\% dan berhasil mengoptimasi waktu pemrosesan.

Untuk mengatasi beberapa kekurangan dari metode yang telah digunakan oleh beberapa penelitian di atas, penelitian ini mengusulkan proses inspeksi kecacatan kaleng dengan mengaplikasikan filter warna HSL dan template matching berbasis contour analysis yang dilakukan secara otomatis tanpa bantuan operator. Filter warna HSL dipilih karena filter HSL merupakan filter warna yang tidak sensitif terhadap perubahan cahaya di sekitar objek. Filter warna HSL akan digunakan untuk mendeteksi kaleng dan memisahkan citra kaleng dari citra latar. Sementara template matching berbasis contour analysis digunakan untuk mengklasifikasi kaleng menjadi kaleng dengan kategori $\mathrm{OK}$ atau reject. Selain karena metode template matching ini mempunyai waktu pemrosesan yang relatif cepat, juga mempuyai tingkat akurasi yang tinggi. Dengan menggabungkan kedua metode tersebut, tingkat keakurasian pengujian akan menjadi lebih baik.

Selanjutnya untuk memudahkan pembahasan, artikel ini disusun sebagai berikut. Sesi dua berisikan metode penelitian yang penulis lakukan. Hasil pengujian dan pembahasan ditempatkan di sesi tiga. Terakhir kesimpulan dipaparkan di sesi empat.

\section{Metode}

Proses inspeksi diawali dengan pengambilan citra oleh kamera. Citra yang tertangkap kamera merupakan citra RGB yang akan dikonversi ke citra aras keabuan (gray level). Untuk dapat mendeteksi kecacatan kaleng, penulis memakai filter luminance dari ruang warna HSL. Proses template matching diterapkan pada masing-masing citra dengan cara membandingkan citra template sebagai citra referensi dengan citra uji. Template yang digunakan adalah bentuk lingkaran dari kaleng yang tampak dari atas. Data template yang disimpan berupa data titik pada setiap keliling lingkaran. Dengan membandingkan jarak antara diameter kaleng template pada tiap titik uji dengan kaleng sampel, kaleng diklasifikasikan menjadi dua kategori yaitu kaleng OK (Good) atau kaleng reject. Kriteria uji yang digunakan adalah jarak masing-masing pixel pada tiap lingkaran kaleng dengan lingkaran pada kaleng template.

\section{a. Citra RGB (Red, Green dan Blue)}

Sebuah citra didefinisikan sebagai fungsi dua dimensi dari pasangan koordinat yang menyatakan posisi dari titik citra dan nilai intensitas atau gray level dari citra di titik tersebut. Jika nilai intensitas atau derajat keabuan citra tersebut dilakukan proses kuantisasi dan pada pasangan koordinat dilakukan proses sampling, maka hasil dari kedua proses tersebut akan menghasilkan citra digital. Citra digital terdiri dari elemen-elemen gambar atau pixel (picture elemen) yang mempunyai lokasi dan intensitas tertentu. Citra RGB adalah citra asli hasil penangkapan kamera. Citra RGB mempunyai tiga kanal warna Red, Green dan Blue yang masing-masing mempuyai 256 level warna dari 0-255.

\section{b. Citra Aras Keabuan (Gray Scale Image)}

Citra keabuan merupakan citra yang nilai intensitas pikselnya didasarkan pada derajat keabuan. Pada citra keabuan, derajat warna hitam sampai dengan putih dibagi ke dalam 256 derajat keabuan di mana warna hitam sempurna direpresentasikan dengan nilai 0 dan putih sempurna dengan nilai 255 .

Citra RGB dapat dikonversi menjadi citra keabuan yang hanya mempunyai satu kanal warna. Persamaan yang umumnya digunakan untuk mengkonversi citra RGB menjadi citra keabuan ditunjukkan pada rumus (1).

citra keabuan $=0.298 * R+0.587 * G+0.114 * B$

\section{c. Filter Citra HSL}

Warna HSL (Hue, Saturation, Luminance) merupakan salah satu warna yang digunakan untuk memfilter (membedakan) objek yang satu dari objek lainnya. Warna HSL banyak digunakan sebagai filter objek berwarna terutama jika keadaan latar yang berubah-ubah karena pengaruh cahaya. Dibanding warna aslinya RGB, warna HSL lebih mudah digunakan untuk membedakan objek yang satu dengan objek lainnya. Gambar 1 menunjukkan contoh konversi citra dari RGB ke HSL.

Konversi warna RGB ke warna HSL ditunjukkan dalam rumus (2).

$$
\begin{aligned}
& r=\frac{K}{255} ; g=\frac{G}{255} ; b=\frac{B}{255} \\
& d=\max (r, g, b)-\min (r, g, b) \\
& L=\frac{\max (r, g, b)+\min (r, g, b)}{2} \quad \text { if } d=0 \\
& H= \begin{cases}\frac{0,}{d 0(G-B)}, \quad \text { if } \max =r \\
120+\frac{60(B-R)}{d}, \text { if } \max =g \\
240+\frac{60(R-G)}{d}, \text { if } \max =b\end{cases} \\
& s= \begin{cases}0, \quad \text { if } d=0 \\
\frac{\max (r, g, b)+\min (r, g, b)}{d}, & \text { if } L<0.5\end{cases}
\end{aligned}
$$

Besarnya nilai dari HSL ini adalah sebagai berikut: $0 \leq L \leq 1,0 \leq S \leq 1$, dan $0 \leq H \leq 360^{\circ}$. 


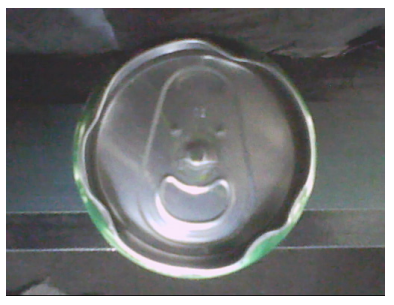

a. Original image

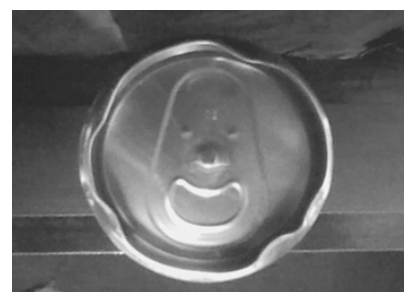

b. HSL image

Gambar 1. Konversi Citra RGB ke HSL

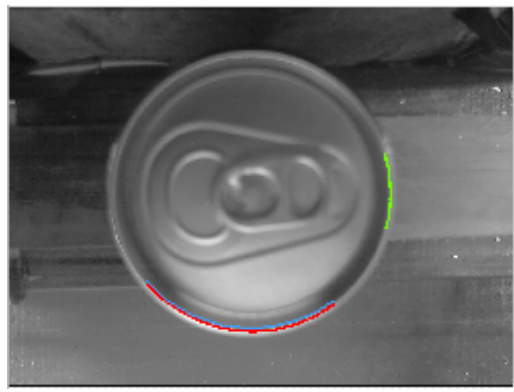

Gambar 2. Ekstraksi template

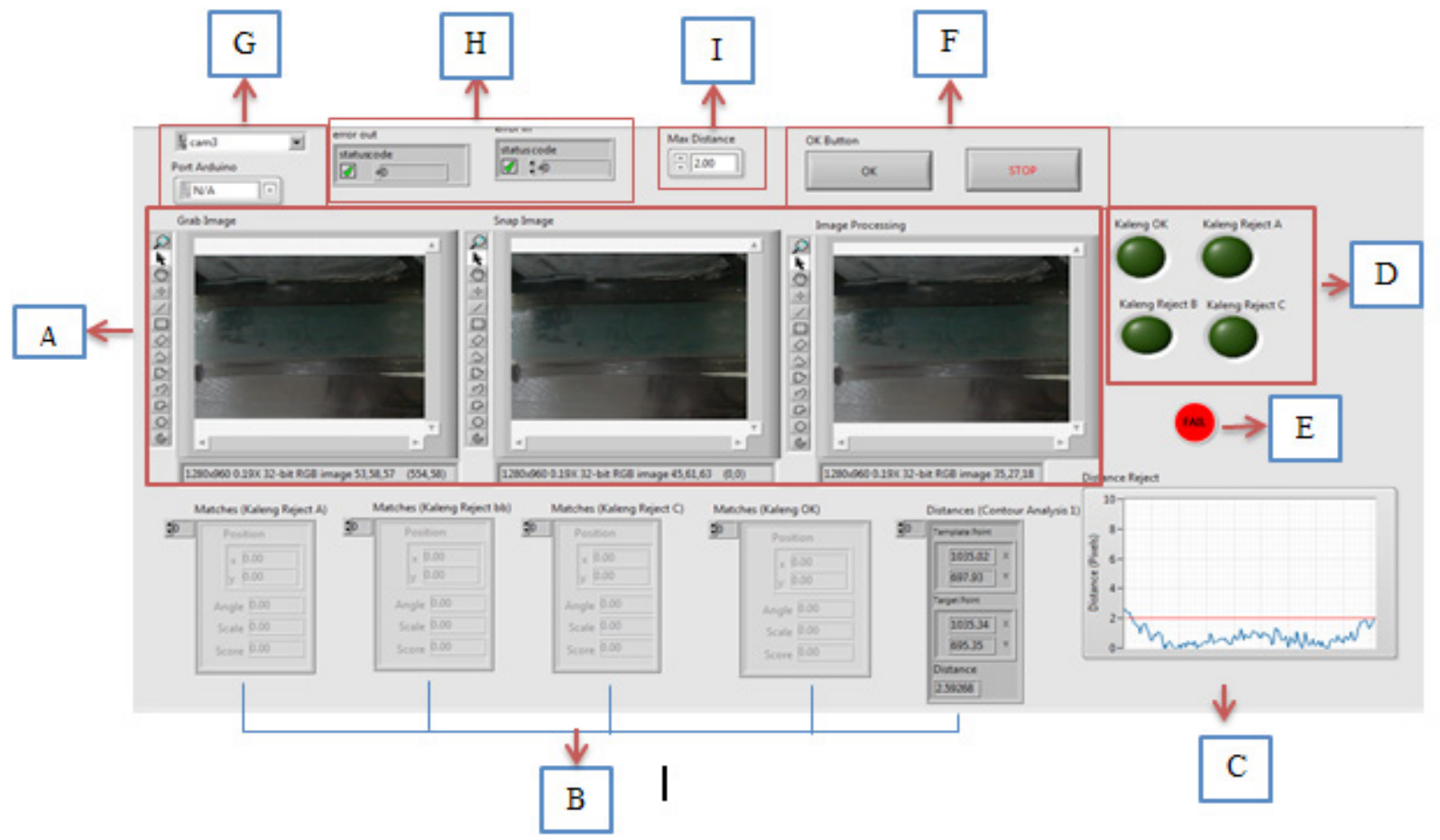

16

Gambar 3. Tampilan interface aplikasi

\section{d. Template Matching}

Template matching adalah suatu proses membandingkan suatu citra template (referensi) dengan citra uji dengan suatu kriteria matching. Bagian ini merupakan bagian kunci yang menentukan keberhasilan proses pengklasifikasian kaleng. Dalam artikel ini digunakan template matching berbasis contour analysis, yaitu template matching yang didasarkan pada penghitungan kemiripan contour antara objek yang diuji dengan objek referensi. Proses template matching dilakukan setelah didapatkan citra objek yang akan diuji. Citra objek ini didapatkan dari proses filter warna HSL. Proses template matching didahului dengan proses ekstraksi template untuk mendapatkan data ciri dari template yang dibutuhkan sebagai ciri referensi. Gambar 2 menunjukkan hasil ekstraksi titiktitik pada keliling lingkaran kaleng sebagai ciri contour yang akan dianalisis kemiripannya. Garis merah menunjukkan kumpulan titik-titik uji pada template di keliling lingkaran. Setelah template diekstraksi, ciri tersebut disimpan dalam database yang akan dijadikan sebagai template. Ciri objek disimpan dalam bentuk jarak titik-titik dalam garis merah terhadap pusat lingkaran dalam kaleng sebagai contour yang akan dianalisis. 


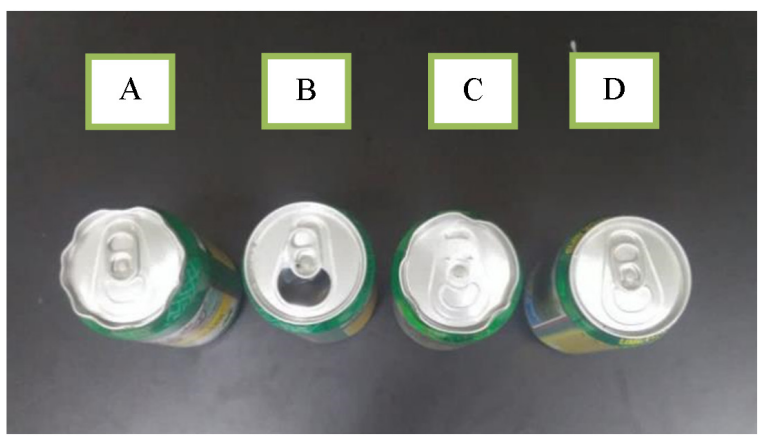

Gambar 4. Sample uji.

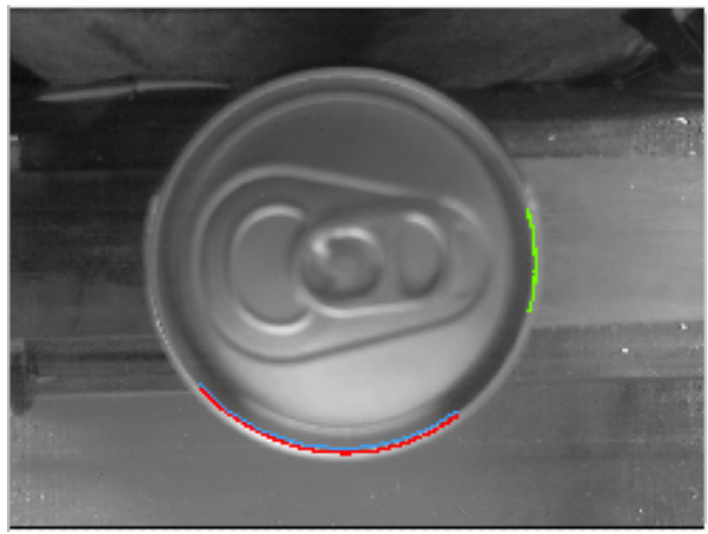

Gambar 5. Sampel uji pada kondisi GOOD $(O K)$

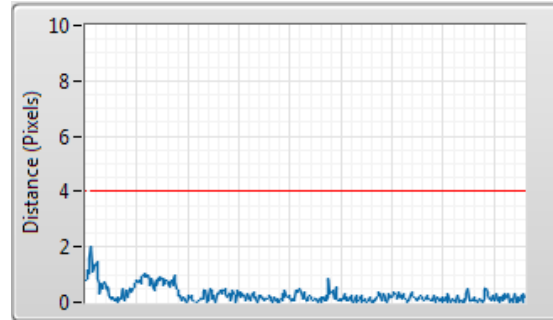

a. Pengujian ke 1

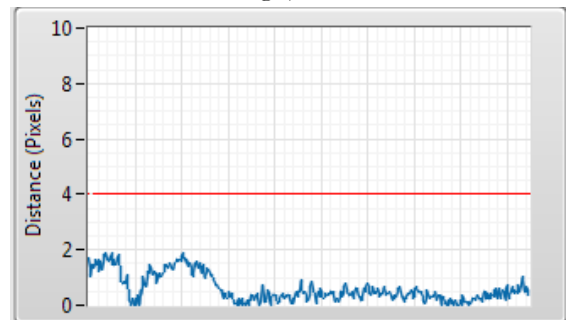

b. Pengujian ke 2

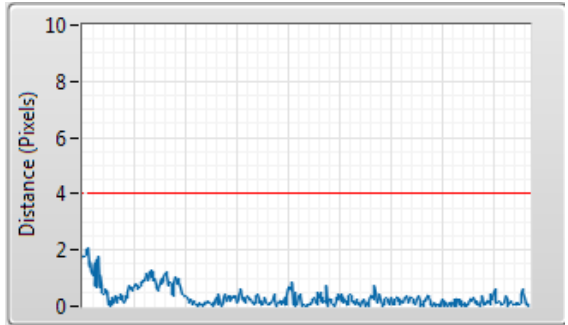

c. Pengujian ke 3

Gambar 6. Hasil pengujian objek OK

Langkah selanjutnya adalah menghitung matching score pada tiap titik uji antara kaleng uji dan kaleng template. Matching score dihitung berdasarkan nilai RMS (Root Mean
Square) dari jarak tiap titik pada kaleng uji ke titik pada

$x_{r m s}=\sqrt{\frac{\sum_{i=1}^{N} x_{1}{ }^{2}}{N}}$

dengan $x$ adalah jarak masing-masing titik ke titik uji template. Objek yang matching akan mempunyai nilai RMS di bawah threshold yang telah ditentukan

\section{Hasil}

Gambar 3 menunjukkan tampilan interface aplikasi yang dibuat berdasarkan NI Labview Vision yang terdiri dari $A$ adalah 3 buah picture box yang berfungsi untuk mengakuisisi frame video, menampilkan gambar dan menampilkan hasil pengolahan gambar, $B$ adalah tampilan untuk memonitoring data yang keluar pada template matching, $C$ adalah grafik yang keluar pada template matching, $D$ adalah indikator untuk membedakan jenis kaleng yang $\mathrm{OK}$ atau reject, $E$ adalah lampu status kaleng $\mathrm{OK}$ atau reject, $F$ adalah tombol OK untuk meng-capture gambar, $G$ adalah combo box untuk memilih port kamera dan arduino yang digunakan, $H$ adalah indikator error apabila sistem mengalami kesalahan, $I$ adalah nilai maksimum distance pixels dalam menentukan nilai kaleng $\mathrm{OK}$ atau reject.

Sampel uji ditunjukkan oleh gambar 4. $A$ adalah kaleng reject 1 dengan diameter yang tidak sesuai. $B$ adalah kaleng reject2 dengan pembuka kaleng terbuka. $C$ adalah kaleng reject3 dengan diameter yang tidak beraturan dan tidak memiliki pembuka kaleng. D adalah kaleng dengan kondisi baik (OK).

Dalam penelitian ini, penulis menggunakan template matching berbasis contour analysis untuk menentukan kriteria reject pada kaleng. Contour analysis akan menghitung kemiripan dua objek dengan menghitung jarak masingmasing titik terhadap titik uji. Dalam pengujian ini, penulis menggunakan lingkaran dengan diameter $4 \mathrm{~cm}$ sebagai template. Proses template matching dilakukan untuk setiap titik dalam lingkaran kaleng yang berjarak kurang dari $4 \mathrm{~cm}$. Dengan membandingkan tiap titik pada semua sampel, kita dapat mengetahui suatu sampel termasuk objek yang $\mathrm{OK}$ atau reject.

\section{a. Pengujian sample dengan kondisi Good (OK)}

Pada pengujian kaleng Good (OK), penulis uji sampel sebanyak 3 kali dengan orientasi peletakan objek yang berbeda. Sampel yang diuji ditunjukkan pada gambar 5 . Garis merah merupakan jarak diameter objek referensi sedangkan warna biru adalah jarak tiap pixel terhadap template lingkaran.

Hasil pengujian ditunjukkan gambar 6. Sumbu $Y$ menunjukkan jarak tiap pixel dan sumbu $X$ menunjukkan posisi titik tersebut pada lingkaran dimulai dari sudut 0-360. Garis merah pada grafik merupakan threshold pada tiap titik sebagai pembatas suatu objek mirip dengan objek referensi. Dari ketiga pengujian di atas didapatkan bahwa tidak ada satu nilai dari posisi titik uji pada kaleng yang melebihi threshold. Nilai RMS hasil pengujian masingmasing yaitu 0,$39 ; 0,74$ dan 0,57 pixels. Sehingga rata-rata RMS untuk ketiga pengujian di atas adalah 0,59 pixels. Hal ini menunjukkan bahwa sample uji masuk kriteria ok $(G O O D)$. 


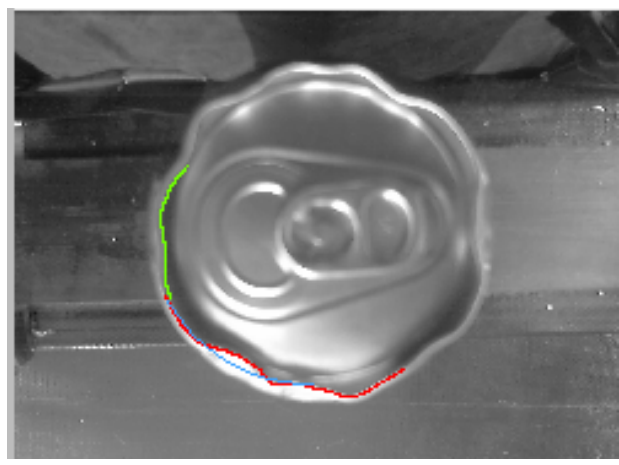

Gambar 7. Sampel uji kaleng reject1

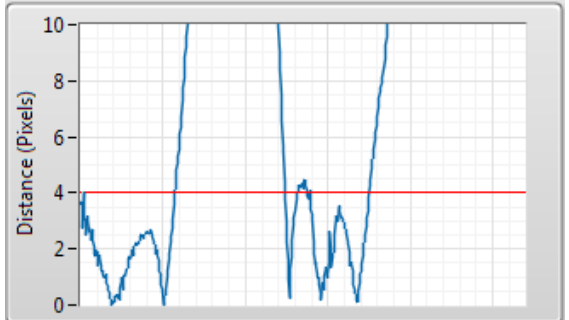

a. Pengujian ke 1

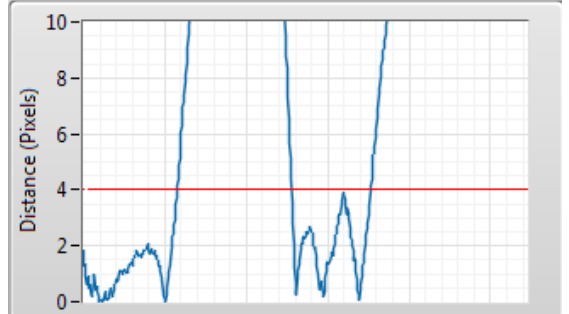

b. Pengujian ke 2

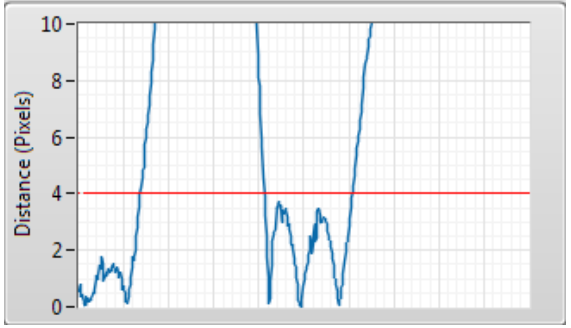

c. Pengujian ke 3

Gambar 8. hasil pengujian objek reject1

\section{b. Pengujian sample reject 1}

Pada pengujian kaleng reject 1 (kaleng dengan diameter yang tidak sesuai), penulis uji sampel sebanyak 3 kali dengan orientasi peletakan objek yang berbeda. Sampel yang diuji ditunjukkan pada gambar 7. Hasil pengujian ditunjukkan gambar 8.

Dari ketiga pengujian di atas didapatkan bahwa ada beberapa titik dalam kaleng yang jarak pixelnya melebihi threshold. Nilai RMS hasil pengujian masing-masing yaitu 17,39; 20,87 dan 20.51 pixels. Sehingga rata-rata RMS untuk ketiga pengujian di atas adalah 19,59 pixels. Hal ini menunjukkan bahwa sampel uji masuk kriteria reject.

\section{c. Pengujian sample reject 2}

Sampel uji reject2 (kaleng dengan pembuka kaleng terbuka) dan hasil pengujian ditunjukkan oleh gambar 9 dan gambar 10.

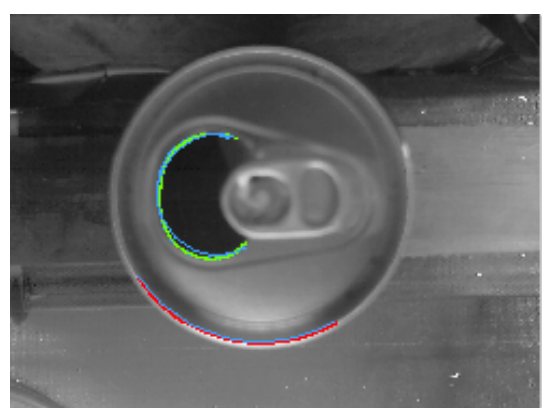

Gambar 9. Sampel uji kaleng reject2

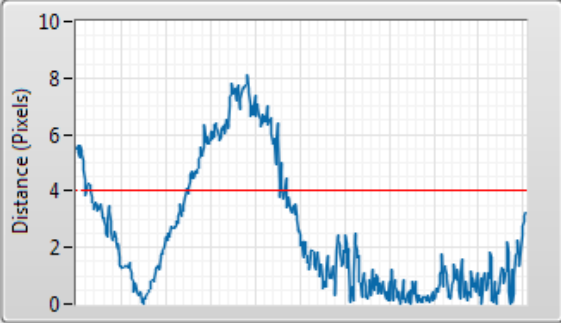

a. Pengujian 1

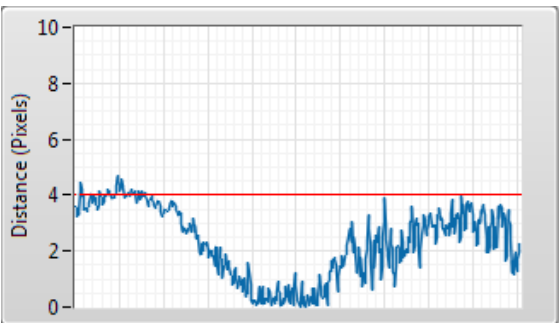

b. Pengujian 2

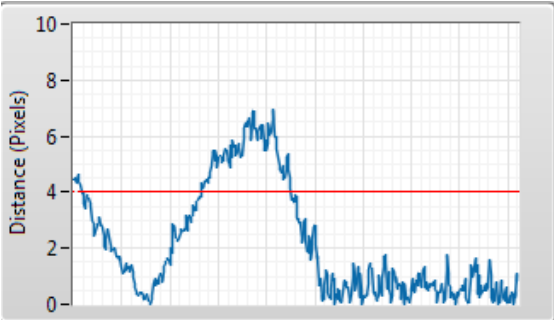

c. Pengujian 3

Gambar 10. hasil pengujian objek reject2

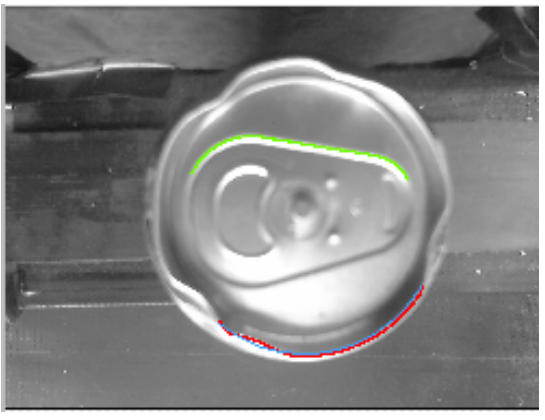

Gambar 11. Sampel uji kaleng reject3

Ketiga pengujian menunjukkan ada beberapa titik dalam kaleng yang jarak pixelnya melebihi threshold. Nilai RMS hasil pengujian masing-masing yaitu 4,72; 5,19 dan 5.24 pixels. Rata-rata RMS untuk ketiga pengujian di atas adalah 5,05 pixels. Hal ini menunjukkan bahwa sampel uji masuk kriteria reject. 


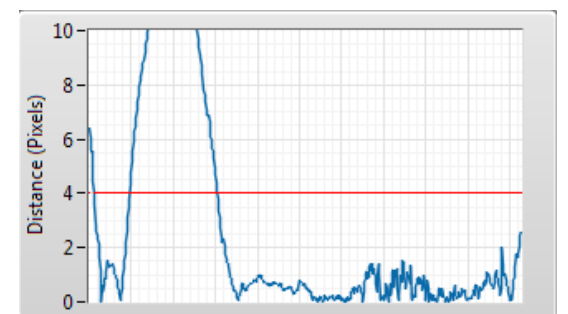

a. Pengujian ke 1

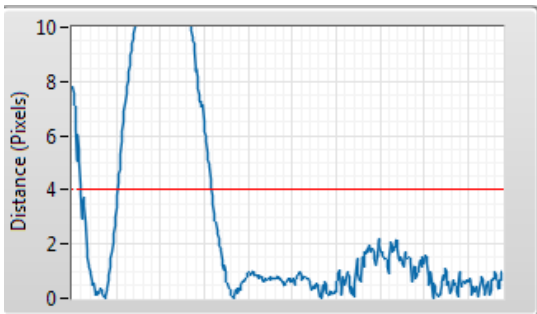

b. Pengujian ke 2

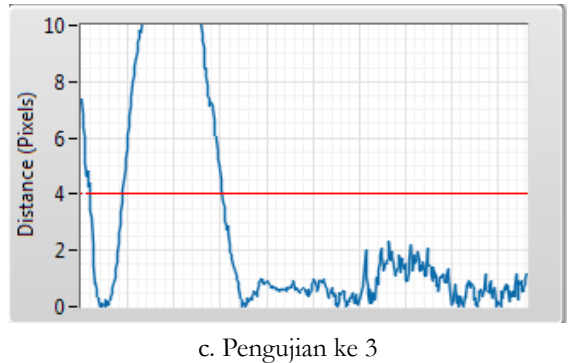

Gambar 12. hasil pengujian objek reject3

jarak pixel pada setiap kaleng

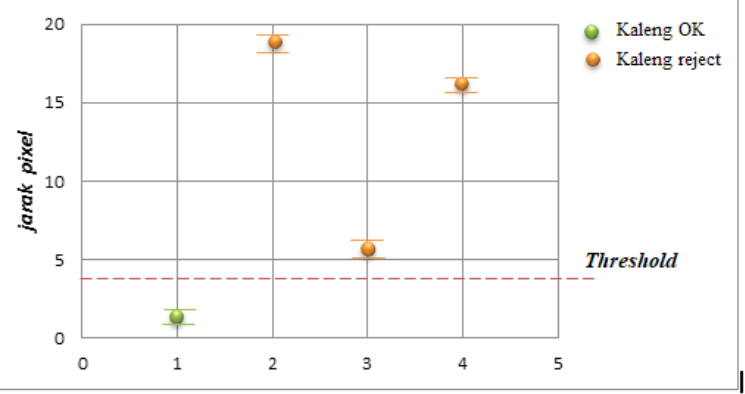

Gambar 13. Grafik jarak rata-rata pixel pada setiap kaleng pengujian

\section{d. Pengujian sample reject 3}

Sampel uji reject3 (kaleng tanpa pembuka kaleng terbuka dan diameter tidak beraturan) dan hasil pengujian ditunjukkan oleh gambar 11 dan gambar 12.

Ketiga pengujian menunjukkan ada beberapa titik dalam kaleng yang jarak pixelnya melebihi threshold. Nilai RMS hasil pengujian masing-masing yaitu 14,72, 15,19 dan 15.24 pixels. Rata-rata RMS untuk ketiga pengujian di atas adalah 15,05 pixels. Hal ini menunjukkan bahwa sampel uji masuk kriteria reject.

Dari keempat pengujian yang dilakukan (1 kaleng Ok dan 3 kaleng reject), didapatkan jarak pixel rata-rata untuk masing-masing kategori digambarkan dalam grafik pada gambar 13. Terlihat bahwa untuk kaleng dengan kategori OK, nilai jarak pixel berada di bawah nilai threshold, sementara 3 kaleng reject mempunyai jarak pixel di atas threshold.

\section{Kesimpulan}

Penelitian ini menerapkan filter warna HSL untuk mendeteksi objek kaleng dari citra yang tertangkap kamera dan melakukan penklasifikasian objek dalam kategori OK atau reject menggunakan template matching berbasiskan contour analysis. Filter HSL dapat mendeteksi objek kaleng dengan baik dalam kondisi latar yang berubah. Template matching berhasil mengklasifikasi objek melalui tiga kali pengujian dengan orientasi dan posisi objek yang berbeda. Objek berhasil diklasifikasi dengan baik dalam dua kategori OK atau reject. Dengan menerapkan nilai threshold sebesar 4, didapatkan nilai RMS untuk objek kategori OK adalah 0,59 . Sementara untuk objek kategori reject didapatkan nilai RMS sebesar 19,59; 5,05; dan 15, 05 berturut-turut untuk objek reject karena diameter tidak beraturan, objek reject dengan pembuka kaleng terbuka dan objek reject dengan tanpa pembuka kaleng.

Penelitian ini masih perlu ditingkatkan terutama dalam pendeteksian objek yang reject sedikit seperti diameter hanya di satu sisi yang berbeda. Hal ini masih memungkinkan dikategorikan objek good. Perbaikan perlu dilakukan dengan menambahkan kriteria klasifikasi lainnya seperti pixel matching. Ini masih tersisa untuk penelitian selanjutnya.

\section{Daftar Pustaka}

[1] V. Mosorov and J. Nowakowski, "Image Defect Detection Methods for Visual Inspection Systems," in Proceeding of International Conference on the Experience of Designing and Application of CAD Systems in Microelectronics, 2007.

[2] A. Addien and P. W. Laksono, "Analisis Pengendalian Kualitas Coca-Cola Kaleng Menggunakan Statistical Process Control pada PT CCAI Central Java," in Prosiding Seminar dan Konferensi Nasional, pp. 8-9, 2017.

[3] B. Sugandi, "Deteksi dan Pelacakan Wajah Berdasarkan Warna Kulit Menggunakan Partikel Filter," J. Rekayasa Elektr., vol. 14, no. 2, pp. 116122, 2017.

[4] K. Basha, P. Ganesan, V. Kalist, B. S. Sathish, and J. M. Mary, "Comparative Study of Skin Color Detection and Segmentation in $\mathrm{HSV}$ and $\mathrm{YCbCr}$ Color Space," Procedia - Procedia Comput. Sci., vol. 57, pp. 41-48, 2015.

[5] R. Wijanarko and N. Eko, "Deteksi Wajah Bebasis Segmentasi Warna Kulit Menggunakan Ruang Warna YCbCr dan Template Matching," J. Ilm. Cendeikia Eksakta, vol. 2, no. 1, pp. 1-6, 2017.

[6] N. Izzati, N. Anis, M. Razali, and H. Achmad, "Fire Recognition Using RGB and YCBCR Color Space," J. Eng. Appl. Sci., vol. 10, no. 21, pp. 97869790, 2015.

[7] M. Balcilar, M. F. Amasyali, and A. C. Sonmez, "Moving Object Detection using Lab2000HL Color Space with Spatial and Temporal Smoothing," J. Appl. Math. Inf. Sci., vol. 1766, no. 4, pp. 1755-1766, 2014. 
[8] S. Tsai and Y. Tseng, "A novel color detection method based on HSL color space for robotic soccer competition," Comput. Math. with Appl., vol. 64, no. 5, pp. 1291-1300, 2012.

[9] A. M. Aibinu, A. A. Shafie, and M. J. E. Salami, "Performance Analysis of ANN based $\mathrm{YCbCr}$ Skin Detection Algorithm," Proceeding Int. Symp. Robot. Intell. Sensors, vol. 41, no. Iris, pp. 11831189, 2012.

[10] N. S. Widodo and A. Rahman, "Vision Based Self Localization for Humanoid Robot Soccer," Telkomnika, vol. 10, no. 4, pp. 637-644, 2012.

[11] E. Budianita and L. Handayani, "Implementasi Pengolahan Citra dan Klasifikasi K- Nearest Neighbour Untuk Membangun Aplikasi Pembeda Daging Sapi dan Babi," J. Sains, Teknol. dan Ind., vol. 12 , no. 2, pp. 242-247, 2015

[12] G. Sharma, "Image Recognition System using Geometric Matching and Contour Detection," J. Comput. Appl., vol. 51, no. 17, pp. 48-53, 2012.
[13] B. Leksono, A. Hidayatno, and R. R. Isnanto, "Aplikasi Metode Template Matching untuk Klasifikasi Sidik Jari,” Transmisi, vol. 13, no. 1, pp. 1-6, 2011.

[14] M. \& S. R. Bianco Simone \& Buzzelli, "Object Detection Using Feature-based Template Matching," Proc. SPIE - Int. Soc. Opt. Eng., 2013.

[15] W. and Y. P. A, "Penggunaan Template Matching untuk Identifikasi Kecacatan pada PCB," in Seminar Nasional Aplikasi Teknologi Informasi, 2008.

[16] I. Pham, R. Jalovecky, and M. Polasek, "Using template matching for object recognition in infrared video sequences," in Proceeding of IEEE/ ALAA 34th Digital Avionics Systems Conference (DASC), p. 8C5-1-8C5-9, 2015.

[17] A. Banharnsakun and S. Tanathong, "Object Detection Based on Template Matching through Use of Best-So-Far ABC," Comput. Intel. Neurosci., 2014. 